\title{
Amenity Readiness of Rural Tourism in Fatumnasi Village East Nusa Tenggara towards Sustainability
}

\author{
Laurensius Sandro Rero*, Syul Rosli Sanam \\ Tourism Department \\ Kupang State Polytechnic \\ Kupang, Indonesia \\ *sandro.rero@pnk.ac.id, unnyesanam@gmail.com
}

\begin{abstract}
This study aims to analyse the readiness of rural tourism in Fatumnasi towards the sustainability aspect. The method of this research was descriptive qualitative based on an exploratory study, which means that the data collected by qualitative and exploration methods and then describe in descriptive. The data was gathered by observation and in-depth interview with the owner of the homestay, the local guide, and the owner of the souvenir shop, and each of those amenities was explained through the sustainable development aspects like; economic aspect, socio-cultural aspect, and environmental aspect. The result shows that the readiness of homestay, local tour guide, and souvenir shop as an amenity in fatumnasi already meet the sustainable development aspect but still need to be maintained so that the local community can get the benefit from the rural tourism activity in Fatumnasi area.
\end{abstract}

Keywords-rural tourism, sustainable tourism development, amenity, homestay, local tour guide, souvenirshop

\section{INTRODUCTION}

Tourism is one of the largest and fastest growing economic sector in the world and has a considerable role to play in delivering sustainable development in many countries. At the same time, it must be well managed so that it benefits local communities and the natural and cultural environments upon which It depends [1]. A tourism village is a tourist destination or also called a tourism destination, which integrates tourist attractions, public facilities, tourism facilities, accessibility, which is presented in a structure of community life that integrates with applicable procedures and tradition. In developing the tourism village, as the consideration is that the trend of domestic tourist travel has increased from 2013 which only amounted to 250 million trips to 303.4 million trips in 2018, while this increase is due to a better economic level of community income and as well as access to various destinations that are getting better. The government is now starting to promote the concept of developing tourist villages as an answer to the opportunity of domestic tourist travel development. This concept is also in line with the wishes of President Jokowi to make the tourism village as an important aspect in developing the suburbs to strengthen the region and the village in the context of a unitary state [2]. A well strategized rural tourism will benefit tourism stakeholder such as local communities and industry players in term of welfare and also tourists for the good experience with natural and cultural resource [3].

There are four components in developing a tourist destination according to Cooper that need to be considered for the sustainability of its destination that is Attraction, Accessibility, amenity, and ancillary services [4]. Amenity as one of the tourist destination components that important to be analysed in Fatumnasi village for this tourism village can continuously sustainable and give the profit for the local community. The amenity from Fatumnasi village that needs to be analysed is the accommodation like a homestay, local tour guide, souvenir shop, and the indicators of the readiness will be seen under the concept of sustainable tourism development that is an economic aspect, socio-cultural aspect, and environmental aspect.

Based on the background, this research questions were: (1) How the readiness of the Homestay as an amenity for the sustainability of Fatumnasi village seen from the sustainable tourism approach aspect; economically, socio-cultural, and environmentally. (2) How the readiness of the local tour guide as an amenity for the sustainability of Fatumnasi village seen from the sustainable tourism approach aspect; economically, socio-cultural, and environmentally. (3) How the readiness of the souvenir shop as an amenity for the sustainability of Fatumnasi village seen from the sustainable tourism approach aspect; economically, socio-cultural, and environmentally. This study was conducted to analyse the readiness of the amenity of rural tourism in Fatumnasi towards sustainability.

\section{LITERATURE REVIEW}

\section{A. Rural Tourism}

Although tourism is booming globally, rural tourism is still under developed compared to urban tourism despite the tremendous advances made by e-tourism [8]. Rural tourism is still not the first choice of most tourists, probably because of the following challenges highlighted by authors such as [5]. Developing rural tourism has its challenges. any successful 
tourism development, whether prop poor or not, depends on commercial, economic, and logistical issues, such as the quality of the product, accessibility and infrastructure of the destination, availability of skills, and interest of investors [6]. Rural tourism is the tourism development in rural areas, it covers all tourism activities that take place in rural areas that require travel services in the same place [7]. According to World Tourism Organization rural tourism is tourism where rural culture is a key component of recreational tourism product [8].

\section{B. Tourism Component}

There are four tourism component that call 4As: Attraction, Accessibility, Amenities, and Ancillary [9]. This Tourism Components also namely as 4A's Tourism component, which needs to consider as a basic component that tourist destination should have [10]

The development framework of tourism destinations consists of the following main components [9]. (1) The attraction which includes the uniqueness and attractiveness based on nature, culture, or artificial. (2) Accessibility which includes the ease of transportation facilities and systems. (3) Amenities which include supporting facilities and supporting tourism. (4) Public facilities (ancillary service) that support tourism activities. (5) Institutions that have the authority, responsibility, and role in supporting the implementation or tourism activity.

\section{Amenities}

The amenities include a series of facilities to meet the needs of accommodation (lodging), provision of food and beverages, entertainment venues, shopping places (retailing) and other services [11]. amenity is not an attraction for tourists, but with lack of amenities will make tourists avoid certain destination [11].

\section{Sustainable Tourism Development}

Sustainability tourism is tourism and associated infrastructure that: both now and in the future operate within natural capacities for the regeneration and future productivity of natural resources; recognize the contribution that people and communities, customs and lifestyles, make to the tourism experience; accept that these people must have an equitable share in the economic benefits of local and communities in the host area [8]. United World Tourism Organization state that sustainability principles refer to the environmental, economic, and socio-cultural aspects of tourism development, and a suitable balance must be established between these three dimensions to guarantee its long-term sustainability. Thus sustainable tourism should (1) make an optimal use of environmental resource that constitute a key element in tourism development, maintaining essential ecological processes and helping to conserve natural heritage and biodiversity. (2) Respect the socio-cultural authenticity of host communities, conserve their built and living cultural heritage and traditional values, and contribute to inter-cultural understanding and tolerance. (3) Ensure viable, long-term economic operations, providing socio-economic benefits to all stakeholders that are fairly distributed, including stable employment and incomeearning opportunities and social services to host communities and contributing to poverty alleviation.

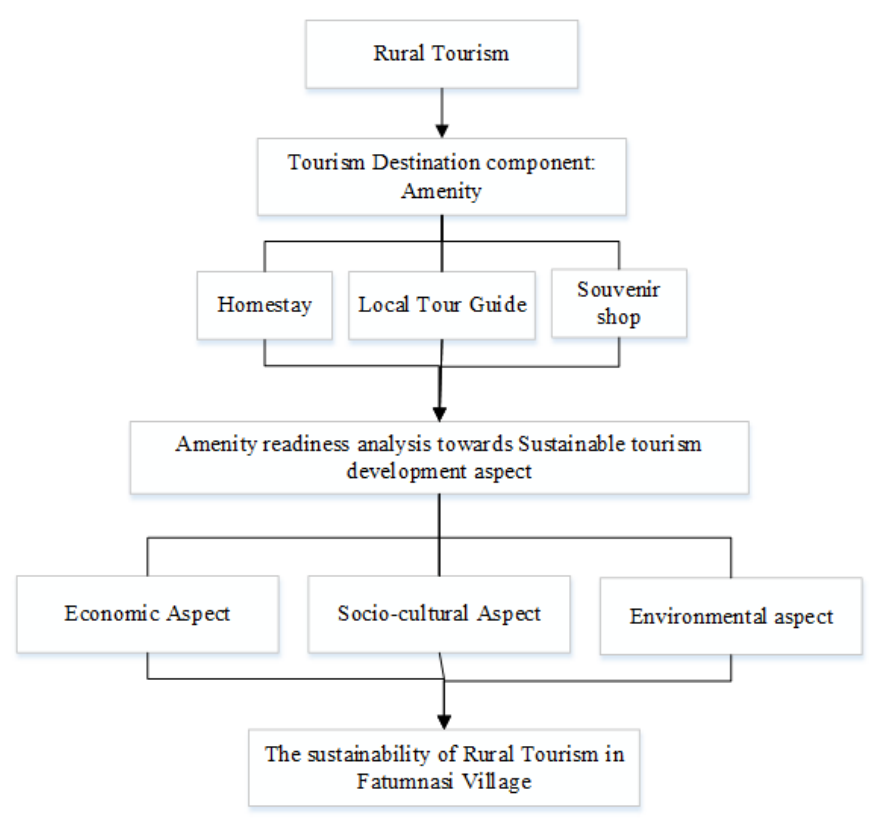

Fig. 1. Research framework

\section{METHODS}

The method of this research was descriptive qualitative based on exploratory study, which means that the data collected by qualitative and exploration method and then describe in descriptive. The data was gathered by observation and in-depth interview to the owner of the homestay, the local guide, and the owner of the souvenir shop.

The primary data collected through observation and interview surroundings area. There were also secondary data supporting to ensure the primary data. Also, the researcher experiences the amenity in the rural tourism area to gain personal perspective and judgement. We conducted semi structured interviews (approximately an hour and a half for each person) with two (2) policy makers (one of the policymakers is an indigenous person and the other one is Head of tourism and creative economic department south centre timor regency) and, three (3) stake holders of amenity like; one (1) the owner of Lopo Mustis Homestay, one (1) the owner of souvenir shop and one (1) local tour guide and we are also compare with the respond from the three (3) guests who come to Fatumnasi. All the participants were chosen because the researchers could easily explore topics more deeply by asking the participants to explain their answer or elaborate on their responses.

Researchers also made observations related to amenity readiness of rural tourism in Fatumnasi towards sustainability. 
The observations made are that the authors observe the conditions of the Fatumnasi village in terms of its environmental aspect like how the community conserves the forests and how the government supports the community in developing rural tourism, the second is related to the sociocultural aspect of the local community like how the community preserves their local genuine and their culture as the main attraction from this village and the third is related to the economical aspect like the benefits obtained by the local community due to tourism activities in this village. All observations made are summarized with the results of the interview and processed then presented in the discussion.

\section{DISCUSSION}

\section{A. General Information about Fatumnasi Rural Tourism Area}

Fatumnasi village located in the district of Fatumnasi, South Central Timor Regency, East Nusa Tenggara Province. This village offers a natural beauty and traditional culture of highland of Timor. The attractions of this rural tourism are mount Mutis (the highest mountain in Timor island), Fatukoto Lake, Oehala waterfall, the traditional ikat weaving.

\section{B. The readiness of the Homestay as an Amenity for the Sustainability of Fatumnasi Village Seen from the Sustainable Tourism Approach Aspect; Economically, Socio-Cultural and Environmentally}

One homestay which is a place to research the tourist village of Fatumnasi is Lopo Mutis homestay. The homestay has been around for a long time and the first homestay in the Fatumnasi village. The owner of this homestay is Mr. Mateus Anin. He is a direct descendant of the Anin Fuka clan which is the first inland tribe to occupy the village of Fatumnasi besides he is also a highly respected figure in the village of Fatumnasi.

In this study, the approach used in analysing the homestay's preparedness is in-depth interviews with key informants and preparing questions related to the approach to sustainable tourism in terms of economic, socio-cultural, and environmental aspects.

1) The readiness of homestay from economic aspect: The result from this aspect showed that the homestay in Fatumnasi village gives the profit from the economic aspect. Based on interviews with Mr. Mateos at the beginning of the homestay until now Mr. Mateos gave freedom to guests to pay the cost of their overnight stay meaning that according to the willingness of guests to pay whatever they will receive. But specifically for foreign guests who stay, he set the price of IDR 100,000, / night which sometimes also includes food and drink provided by Mr. Mateos to foreign guests. Inside the homestay, 3 beds mean if he put price IDR 100,000/ night and divided into three people inside the room that means each guest just pays around IDR 30,000. By that cost, if related to one of the sustainable tourism operational frameworks, namely economic capacity, that is, building the economic capacity of local tourism industry actors/actors to have the high global capacity, capability, and competitiveness, to be able to obtain significant economic benefits sustainably. It is shown that Mr. Mateos needs to revise his policy about the set price for the guests who want to stay at his homestay to give him sustainable economic profit and also for other people in Fatumnasi village who want to do business as Mr. Mateos did.

2) The readiness of homestay from socio-cultural aspect: Based on the results of interviews with Mr. Mateos Anin related to preserving local culture Fatumnasi, the form of homestay buildings made is different from homestays in other places because according to him the homestays are made showing local wisdom and as a form of preservation of local culture not only in terms of the physical form of the building but there is also a philosophical message. This is found in the way of entering the "Lopo" or homestay which is where when entering the door forcing guests or visitors to bow slightly this turns out to be a hereditary moral message that is inherited that is if bowing is an attitude of respect to God, respect for nature, respect to the ancestors and also to the host. This is also following one of the principles of sustainable tourism which is to uphold and respect local wisdom and still maintain its uniqueness in every tourism development.

3) The readiness of homestay from environmental aspect: According to Mr. Mateos, it is very important to protect the environment, because this environment makes fatumnasi has its beauty, has abundant natural products and according to him fatumnasi village community is very concerned about the environment. After all, people are aware that guests come to visit because this village has a natural beauty and a unique air mountainous areas as well as when there are guests who come there will be a buying and selling process and for the people of this village, feel this as a blessing and therefore will be maintained continuously.

The observations saw that there are still trees and plants that are fertile around the homestay, which means that the environment is very much taken care of by the community because the average income of the community is around from agricultural products. Besides, this homestay structure is around $90 \%$ of the material used is environmentally friendly, and does not damage the surrounding plants. This must be preserved so that even though it is in a modern era, it still maintains buildings that uphold the value of local wisdom and are friendly to the surrounding environment.

\section{The Readiness of the Souvenir Shop as an Amenity for The Sustainability of Fatumnasi Village Seen from the Sustainable Tourism Approach Aspect; Economically, Socio-Cultural and Environmentally}

The next analysis that is examined is related to the readiness of amenities in this case the Souvenir Shop for the sustainability of the Fatumnasi Tourism Village. This amenity as one that was raised for analysis is related to its readiness by 
using a sustainable tourism approach that is in terms of economic, socio-cultural, and environmental.

The souvenir shop in Fatumnasi Tourism Village is owned by Mrs. Wasti Sabneno Anin. In the souvenir shop, she provides and making woven fabrics with distinctive motifs from the Molo tribe and also processing local food ingredients and then selling them to guests who come to visit the Fatumnasi Tourism Village.

1) The readiness of Souvenir shop from economic aspect: The first time Mrs. Wasti start her business only with IDR 40,000 After that he participated in the training given by the government on how to process local foodstuffs such as bananas and sweet potatoes so that they could be sold as snacks to guests who visited Fatumnasi Tourism Village. Now, with the business she is going through, Mrs. Wasti can send her children to college and Mrs. Wasti said there is an economic advantage over the business.

Based on observations during the research, it was apparent that Mrs. Wasti's souvenir shop business was the only complete shop selling souvenirs such as woven fabrics of various motifs and sizes, various processed foods ranging from bananas, sweet potatoes, potatoes, and herbal oil and in this souvenir shop also sell the flowers, strawberry plants, and fresh vegetables. If related to one of the sustainable tourism operational frameworks, namely economic capacity, that is, building the economic capacity of local tourism industry actors/actors to have the high global capacity, capability, and competitiveness, to be able to obtain significant economic benefits sustainably, the souvenir shop is already practiced the benefit from the economic aspect of sustainable development.

2) The readiness of souvenir shop from socio-cultural aspect: The question given is related to how Mrs. Wasti preserved culture through the business that she runs. Mrs. Wasti said that the first is a woven cloth that was sold was not only bought from the community but also made by Mrs. Wasti and the motives made were Molo tribal motifs. This woven fabric has different colors and motifs and each color and motif has its meaning. Mrs. Wasti said that she understood very well the meaning of each type of woven fabric that was made and sold, because as a form of preserving there and culture that had been passed down by the ancestors. Not only that, but she also explained that this is also a form of introducing the culture of the Timorese people, especially Fatumnasi Village to the outside community and must be maintained so that tourists want to come to visit because there is something unique that can be found from Fatumnasi Village.

Following the principles of sustainable tourism development which respects and maintains local wisdom, traditions, customs, and culture; develop understanding and tolerance between cultures. The souvenir shop has its way to preserve the local culture.

Based on the principle of sustainable tourism in terms of the environment emphasizes the optimal use of natural resources, carrying out appropriate environmental management efforts to maintain biodiversity. Almost all the communities around the Fatumnasi tourism village were well aware of environmental preservation.

It is also proven that The greatest degree of conformity is on natural tourist attraction assessment items Fatumnasi District by $96 \%$ means that the attraction presented in form of mountain nature tourism, scenery, cool air, forest protected can be under expectations and level of perceived reality traveller.

3) The readiness of souvenir shop from environtmental aspect: Mrs. Wasti explained her argument related to the responsibility to preserve the environment, that the environment for the people of Fatumnasi village is very important because it is a source of livelihood. The average community farms and lives from the garden.

\section{The Readiness of the Local Tour Guide as an Amenity for the Sustainability of Fatumnasi Village Seen From the Sustainable Tourism Approach Aspect; Economically, Socio-Cultural and Environmentally}

As one of the things that are the main focus of this study is related to the readiness of guides for the sustainability of the Fatumnasi tourism village. This analysis is also carried out with a sustainable tourism approach that is related in terms of economic, social, cultural, and environmental.

1) The readiness of local tour guide from economic aspect: In terms of economics, the local tour guide feels there is an economic benefit from this work. As a local guide in his village, Mr. Martinus also join with the group of tourism awareness that was formed by the department of tourism and the creative economy incorporation with the local community. At this present there still a problem with the determination of fee for a local guide in Fatumnasi village. Therefore it should be fixed so that the community in Fatumnasi has the motivation to become a local guide. According to the chief of the local group of tourism awareness, there are 12 people right now listed as a local tour guide. Sometimes the problem not only about the determination about the fee but also comes from the outside guide who comes from outside the Fatumnasi village. The chief said they need the government to help them in making any regulation about only local guide can accompany the guests to have a tour in Fatumnasi village area.

If related to one of the sustainable tourism operational frameworks, namely economic capacity, that is, building the economic capacity of local tourism industry actors/actors to have the high global capacity, capability, and competitiveness, to be able to obtain significant economic benefits sustainably, the local guide is already practiced the benefit from the economic aspect of sustainable development, however, the other problem need to be discussed between the local community and the government.

2) The readiness of local tour guide from socio-cultural aspect: Mr. Martinus said that how the local tour guide 
preserves the culture or local wisdom of Fatumnasi village is by using woven cloth when welcoming guests or accompanying guests, then by maintaining respect for the tribal leader when there are guests who ask questions related to sacred places or sites that should only be explained by the authorities, in this case, the elders who have rights to explain.

This was also explained by Mr. Mateos as a community leader that, it was indeed passed down by an ancestor and was obliged to be followed by all communities. Apart from the fact that the rules should be followed by the community, the explanation regarding the place or cultural sites in the Fatumnasi Village is also to give the right information for the guest who comes to Fatumnasi village.

Under the principles of sustainable tourism development which respects and maintains local wisdom, traditions, customs, and culture; develop understanding and tolerance between cultures, the local tour guide already preserves their local wisdom and culture.

3) The readiness of local tour guide from environtmental aspect: Mr. Martinus as a tour guide who is a member of the tourism awareness group Fatumnasi Village obtained information related to how the role of guides in preserving the environment explained that he was very concerned about the cleanliness of the environment around Fatumnasi village and the objects that became an attraction for visitors such as the mountain mutis. Following the principle of sustainable tourism in terms of the environment emphasizes the optimal use of natural resources, carrying out appropriate environmental management efforts to maintain biodiversity. This amenity put their hard work to keep the environment clean and preserved very well.

The current paradigm of sustainable tourism development is based on the principles that this kind of development should: (1) meet the needs and wants of the local host community in terms of improved living standards and quality of life; (2) satisfy the demands of tourists and the tourism industry and continue to attract them to meet the first aim; and (3) safeguard the environmental resource base for tourism, encompassing natural, built and cultural components, to achieve both of the preceding aims [9]. Sustainability principles refer to the environmental, economic, and sociocultural aspects of tourism development, and a suitable balance must be established between these three dimensions to guarantee its long-term sustainability. Thus, sustainable tourism should: (1) Make optimal use of environmental resources that constitute a key element in tourism development, maintaining essential ecological processes, and helping to conserve natural heritage and biodiversity. (2) Respect the socio-cultural authenticity of host communities, conserve their built and living cultural heritage and traditional values, and contribute to intercultural understanding and tolerance. (3) Ensure viable, long-term economic operations, providing socio-economic benefits to all stakeholders that are fairly distributed, including stable employment and income-earning opportunities and social services to host communities, and contributing to poverty alleviation [9] according to the principle sustainable tourism above, analysis of the readiness of amenity in accordance of sustainability of Fatumnasi tourism village need to create a good participating from the local community, government and the stakeholders and inspired by the concept of the sustainable tourism development the recommendations are as follows. (1) The department of tourism and creative economy south centre Timor regency with the sub-district of the Fatumnasi government should always maintain and support the local community by providing basic training from hard skill and soft skill competency because the people have goodwill to keep tourism activity as an income sector. (2) The tourism board cooperates with provider and travel agents to organize contests and collaborate with stakeholders (e.g., university, NGO) to educate this sustainability to the society, visitors, and staffs, specifically about the amenities that are; homestay, local tour guide, and souvenir shop (3) Ensuring and monitoring the operation of the groups i.e. tourism awareness group, local community group running properly and spread through all the fatumnasi villagers. (4) The Government both the regency and the province should Provide better access i.e. road to reach Fatumnasi Village so that to increase the tourist travel motivation to come to the village.

\section{CONCLUSION}

There are 3 main analysis in this research that can improve the readiness of amenity in Fatumnasi tourism village in accordance to sustainable development in this village, namely; (1) the readiness of homestay based on the economy showed that the owner needs to revise his policy about the set price for the guests who want to stay at his homestay to give him a sustainable economic profit, from socio-cultural aspect showed that the owner already preserved its local culture by the design of the building and also the shape of the door of the homestay, from the environmental aspect of the homestay already practiced the sustainable development which can be seen almost $90 \%$ of its material is eco-friendly. (2) the readiness of souvenir shop based on the economic aspect showed that the owner already practiced the benefit from the economic aspect of sustainable development, from the socio-cultural aspect the owner has practiced the socio-cultural concept by preserving the cultural from the good that been sold that understood very well the meaning of each type of woven fabric that was made and sold, because as a form of preserving there and culture that had been passed down by the ancestors, from the environment aspect mostly the community aware about the importance of carrying out the appropriate environment to maintain biodiversity. (3) the readiness of local tour guide from the economic aspect showed that the worker has a profit but need to be fixed about the fee when guidance guest in Fatumnasi area. From the socio-cultural in line with the principles of sustainable tourism development which respects and maintains local wisdom, traditions, customs, and culture; develop understanding and tolerance between cultures, the local tour guide already preserved their local wisdom and culture and from the environment aspect the worker was very concerned about the cleanliness of the environment around Fatumnasi 
village and the objects that became an attraction for visitors such as the Mutis mountain. To overcome the limitation, the next study may improve the quantitative analysis toward tourist satisfaction in the rural tourism of Fatumnasi Village about the components of tourism destination namely; attraction, amenities, and ancillary services.

\section{REFERENCES}

[1] UNWT, Organization, sustainable tourism for development. Madrid: European Commission, 2013.

[2] N. Nawaningsih, Identification of tourism village development potential towards sustainable tourism development, 2018.

[3] C.H. Chee, L.C. May, S. Peter and N. Vikneswaran, "Rural tourism destination competitiveness: A study on Annah Rais Longhouse Homestay, Sarawak," Procedia - Social and behavioral Sciences Elsevier Ltd, p. 36, 2014.

[4] J.F. Cooper, D. Gilbert and S. Wanhill, Tourism Principles and Practice. London: Logman, 1995.
[5] J. Holland, M. Burian and L. Dixey, Tourism in poor rural areas: Diversifying the product and expanding the benefits in rural Uganda and the Czech Republic, 2003.

[6] N. Tsephe and S. Obono, "A theoritical framework for rural tourism motivation factors," International scholarly and scientific research and innovation, vol. 7, p. 273, 2013.

[7] M. Mrkša and T. Gajić, "Opportunities for sustainable development of rural tourism in the Municipality of Vrbas," Economics of Agriculture, vol. 61 , no. 297-2016-3617, pp. 163-175, 2014.

[8] M.R. Dorobuntu, G. Gheorghe and P. Nistoreanu, Competitiveness of agro-food and environmental economy. Bucharest Univarsity of Economic studies, Bucharest, 2012.

[9] A. Basalamah and M. Adiati, "Condition of sustainable tourism in the field social culture based on experience and expectations visitors on the tanjung papuma beach Jember,” Binus Business review, vol. V, 2014.

[10] T. Andrianto and A.G. Sugiama, "The analysis of Potential 4A's tourism component in the Selasari Rural Tourism , Pangandaran, West Java,' The 12th Biennial Conference of Hospitality and Tourism Industry in Asia, no. 4, pp. 0138-0139, 2016.

[11] H.I. Salam, "Strategies to develop sawahlunto old city in west sumatera," Tourism research journal , vol. II, pp. 82, 2018. 